\title{
Correction to: Population data of 21 autosomal STR loci in the Hausa, Igbo and Yoruba people of Nigeria
}

\author{
Victoria O. Okolie ${ }^{1} \cdot$ Selena Cisana ${ }^{2} \cdot$ Moses S. Schanfield ${ }^{2} \cdot$ Alani Sulaimon Akanmu $^{3} \cdot$ Khalid O. Adekoya $^{1}$. \\ Olufemi A. Oyedeji ${ }^{3}$. Daniele Podini ${ }^{2}$
}

Published online: 16 January 2018

(C) Springer-Verlag GmbH Germany, part of Springer Nature 2018

\section{Correction to: Int J Legal Med}

https://doi.org/10.1007/s00414-017-1722-3

In the original paper author Alani Sulaimon Akanmu was erroneously omitted from the author list. Prof. Akanmu has now been added as $4^{\text {th }}$ author. Prof. Akanmu acted as an academic supervisor of the study and additionally contributed to the publication by reading, commenting and editing the manuscript.

The online version of the original article can be found at https://doi.org/ 10.1007/s00414-017-1722-3

Victoria O. Okolie

ogomokolie@yahoo.com

1 Department of Cell Biology and Genetics, University of Lagos,

Lagos, Nigeria

2 Department of Forensic Sciences, The George Washington University, Washington, DC, USA

3 Department of Haematology and Blood Transfusion, College of Medicine, University of Lagos, Lagos, Nigeria 